\title{
IGF-1 protects SH-SY5Y cells against MPP+-induced apoptosis via PI3K/PDK-1/Akt pathway
}

\author{
Chanyang Kim ${ }^{1}$ and Seungjoon Park ${ }^{2}$ \\ 1'Department of Biomedical Science, Graduate School, Kyung Hee University, Seoul, Korea \\ ${ }^{2}$ Department of Pharmacology and Medical Research Center for Bioreaction to ROS and Biomedical Science Institute, School of Medicine, \\ Kyung Hee University, Seoul, Korea \\ Correspondence should be addressed to S Park: sjpark@khu.ac.kr
}

\begin{abstract}
Insulin-like growth factor (IGF)-1 is a well-known anti-apoptotic pro-survival factor and phosphatidylinositol-3-kinase (PI3K)/Akt pathway is linked to cell survival induced by IGF-1. It is also reported that Akt signaling is modulated by 3-phosphoinositidedependent kinase-1 (PDK1). In the current study, we investigated whether the antiapoptotic effect of IGF-1 in SH-SY5Y cells exposed to 1-methyl-4-phenylpyridinium $\left(\mathrm{MPP}^{+}\right)$is associated with the activity of PI3K/PDK1/Akt pathway. Treatment of cells with IGF-1 inhibited MPP+-induced apoptotic cell death. IGF-1-induced activation of Akt and the protective effect of IGF-1 on $\mathrm{MPP}^{+}$-induced apoptosis were abolished by chemical inhibition of PDK1 (GSK2334470) or PI3K (LY294002). The phosphorylated levels of Akt and PDK1 were significantly suppressed after MPP+ exposure, while IGF-1 treatment completely restored MPP+-induced reductions in phosphorylation. IGF-1 protected cells from MPP+ insult by suppressing intracellular reactive oxygen species (ROS) production and malondialdehyde levels and increasing superoxide dismutase activity. Mitochondrial ROS levels were also increased during MPP+ exposure, which were attenuated by IGF-1 treatment. In addition, IGF-1-treated cells showed increased activities of succinate dehydrogenase and citrate synthase, stabilization of mitochondrial transmembrane potential, increased ratio of Bcl-2 to Bax, prevention of cytochrome c release and inhibition of caspase- 3 activation with PARP cleavage. Furthermore, the protective effects of IGF-1 on oxidative stress and mitochondrial dysfunction were attenuated when cells were preincubated with GSK2334470 or LY294002. Our data suggest that IGF-1 protects SH-SY5Y cells against MPP+-associated oxidative stress by preserving mitochondrial integrity and inhibiting mitochondrial apoptotic cascades via the activation of PI3K/PDK1/Akt pathway.
\end{abstract} Key Words
Endocrine Connections (2018) 7, 443-455

\section{Introduction}

Parkinson's disease (PD) is the second most common neurodegenerative disorder after Alzheimer's disease. PD affects $1 \%$ of the population worldwide after the age of 65 years (1). The disease is characterized by a progressive dopaminergic neurodegeneration in the substantia nigra pars compacta (SNpc) and the loss of projecting nerve fibers in the striatum (2), which results in dysfunction of extrapyramidal motor system. Although the precise molecular mechanisms underlying dopaminergic neurodegeneration are not still elucidated, numerous

$$
\begin{array}{lr}
\text { http://www.endocrineconnections.org } & \odot 2018 \text { The authors } \\
\text { https://doi.org/10.1530/EC-17-0350 } & \text { Published by Bioscientifica Ltd }
\end{array}
$$

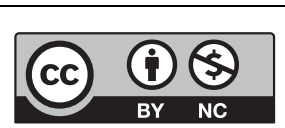


lines of evidence indicate that mitochondrial dysfunction and oxidative stress-mediated apoptosis play an important role in the pathogenesis of PD $(3,4)$. Some neurotoxins, such as 1-methyl-4-phenyl-1,2,3,6-tetrahydropyridine (MPTP), 6-hydroxydopamine (6-OHDA), paraquat and rotenone, are used to model PD and most of these agents are associated with enhanced apoptotic cell death (2). MPTP is the most widely studied neurotoxin in this class, because it selectively destroys dopaminergic neurons in mouse SN. After systemic administration, MPTP is metabolized to the active toxic molecule 1-methyl4-phenylpyridinium ion $\left(\mathrm{MPP}^{+}\right)$, which inhibits the mitochondrial electron transport chain complex I, leading to impaired mitochondrial energy metabolism and enhanced ROS production (5). The resultant oxidative stress and damaged mitochondrial energy metabolism cause broad dopaminergic neurodegeneration in the SNpc (4). Furthermore, it has been shown that $\mathrm{MPP}^{+}$ decreases mitochondrial DNA content (6), resulting in mitochondrial dysfunction and further aggravation of the oxidative stress and subsequent apoptotic cell death (7). Oxidative stress also plays a key role in the depolarization of mitochondrial membrane potential $\left(\Delta \psi_{\mathrm{M}}\right)$ and the release of cytochrome $c$ from the mitochondria into the cytoplasm (4). Upon entry into the cytosol, cytochrome c complexes with the caspase-activating protein Apaf-1, leading to the activation of apoptotic caspase cascade (8). It has been shown that $\mathrm{MPP}^{+}$produces oxidative stress, mitochondrial dysfunction and apoptosis in human neuroblastoma cell line SH-SY5Y $(9,10,11)$. Therefore, the molecules targeting pharmacological intervention of mitochondrial dysfunction and oxidative stressdependent apoptosis induced by $\mathrm{MPP}^{+}$may be promising candidates for neuroprotective agents in PD.

Insulin-like growth factor (IGF)-1, a small peptide composed of 70 amino acids, is a well-known neurotrophic and anti-apoptotic pro-survival factor and plays an important role in the regulation of metabolism, cellular function, growth and differentiation (12). The biologic actions of IGF-1 are mediated via the IGF-1 receptor (IGF-1R), a tyrosine kinase receptor (13). When IGF-1 binds to its corresponding receptor, it triggers downstream signaling pathways, of which the most important is the phosphatidylinositol-3-kinase (PI3K)/Akt pathway (14). The PI3K/Akt pathway has been implicated in the regulation of cell survival (15) and dysregulation of Akt signaling has been observed in PD in vivo and in vitro models $(16,17,18)$. It is known that 3-phosphoinositide-dependent kinase-1 (PDK1) phosphorylates the activation loop of Akt at Thr308 by docking to phosphatidylinositol-3,4,5-triphosphate at the plasma membrane $(19,20)$. However, to the best of our knowledge, the role of PI3K/PDK1 pathway in IGF-1mediated activation of Akt has never been investigated.

IGF-1 could become a potential beneficial therapeutic strategy by improving mitochondrial function, decreasing oxidative stress and preventing apoptosis in a PI3K/Akt-dependent manner $(21,22)$. High expression of IGF-1R in dopaminergic neurons of the SN (23) and increased loss of SN dopaminergic neurons after MPTP injection in IGF-1 $\mathrm{R}^{+/-}$mice (24) suggest that IGF-1 may act as a neuroprotective factor in PD. Indeed, IGF-1 has been shown to act as a survival factor and inhibit apoptosis in PC12 cells (25) and SH-EP1 cells (26) against $\mathrm{MPP}^{+}$ insult. IGF-1 has also been known to successfully reduce the damage after 6-OHDA-induced toxicity in rodent neuronal cultures (27). Based on these observations, it is likely that survival-promoting effect of IGF-1 via the Akt pathway may be at least partly regulated by the activation of PDK1.

In the current study, we hypothesized that the activities and functions of PI3K/PDK1 pathway, upstream of Akt, would be important in the anti-apoptotic effects of IGF-1 against $\mathrm{MPP}^{+}$-induced cell injury. Therefore, to test this hypothesis, we examined the effect of IGF-1 on the survival of SH-SY5Y cells exposed to $\mathrm{MPP}^{+}$insult. SH-SY5Y cells, a cell line from a human neuroblastoma, have many characteristics of dopaminergic neurons, and these cells have been widely used as a model of studying PD-related neurotoxicity, including $\mathrm{MPP}^{+}$(28). To determine the mechanism of IGF-1-induced anti-apoptotic effect, selective inhibitors of PDK1 and PI3K were employed. We also investigated the role of PI3K/PDK1/Akt pathway in the inhibitory effect of IGF-1 on $\mathrm{MPP}^{+}$-induced oxidative stress-mediated apoptosis and mitochondrial dysfunction.

\section{Materials and methods}

\section{Materials}

Human recombinant IGF-1 was obtained from Sigma Chemical. Dulbecco's modified Eagle's medium (DMEM)/F12 was from Gibco/Invitrogen. Primary antibodies to caspase-3, cleaved poly(ADP-ribose) polymerase (PARP), Bcl-2, Bax, cytochrome c, PDK1, Akt and were obtained from Cell Signaling Technology. Bax was purchased from Abcam and $\beta$-actin was from Santa Cruz Biotechnology. LY294002 was obtained from Sigma and GSK2334470 was procured from Tocris (Ellisville, MO, USA). All tissue culture reagents were obtained from

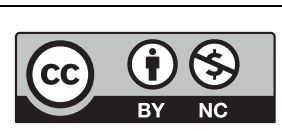

This work is licensed under a Creative Commons Attribution-NonCommercial 4.0 International License. 
Gibco/Invitrogen, and all other reagents were obtained from Sigma unless otherwise indicated.

\section{Cell cultures and treatments}

SH-SY5Y human neuroblastoma cells were maintained in DMEM/F12 supplemented with 10\% fetal bovine serum, $100 \mathrm{U} / \mathrm{mL}$ penicillin and $100 \mathrm{mg} / \mathrm{mL}$ streptomycin in a humidified atmosphere of $5 \% \mathrm{CO}_{2}$. Cells were serum starved for $1 \mathrm{~h}$ before treatment with IGF-1. To determine if IGF-1 protects SH-SY5Y cells from $\mathrm{MPP}^{+}$-induced insult, cells were pretreated with IGF-1 (10 nM) or vehicle (saline) for $1 \mathrm{~h}$. Then, cells were exposed to $1 \mathrm{mM} \mathrm{MPP}^{+}$or vehicle for $24 \mathrm{~h}$. Experiments were also performed by adding the following pharmacological inhibitors to culture media, GSK2334470 $(2 \mu \mathrm{M})$ or LY294002 $(4 \mu \mathrm{M})$. To investigate the effect of IGF-1 on the PI3K/PDK1/Akt pathway, cells were treated with IGF-1 or vehicle for $1 \mathrm{~h}$ in the absence or presence of pharmacological inhibitors and assayed by Western blotting described below.

\section{Assessment of cell death and apoptosis}

Cells viability was measured by the 3-(4,5-dimethylthiazole2-yl)-2,5-diphenyltetrazolium bromide (MTT) assay. Cell death was assessed by the measurement of lactate dehydrogenase $(\mathrm{LDH})$ released from damaged cells in the extracellular fluid using a Cytotoxicity Detection Kit (LDH) (Roche Diagnostics). Histone-complexed DNA fragments were quantified by the Cell Death Detection ELISA (Roche) according to the manufacturer's protocol.

\section{Detection of intracellular and mitochondrial ROS production}

Intracellular ROS levels were assessed using the ROS-sensitive fluorescent dye 2',7'-dichlorofluorescin diacetate (DCFDA) (Sigma-Aldrich). SH-SY5Y cells were incubated with $2.5 \mu \mathrm{M}$ DCFDA for $15 \mathrm{~min}$. For the detection of mitochondrial ROS production, we used the mitochondrial-sensitive dye MitoSOX Red (Molecular Probes). The cells were incubated with $3 \mu \mathrm{M}$ MitoSOX Red for $10 \mathrm{~min}$. Fluorescence was captured using a 630× objective lens on a Carl Zeiss LSM 700 Meta confocal microscope (485-nm excitation and 535-nm emission for DCFDA; 510-nm excitation and 580-nm emission for MitoSOX Red). DCFDA and MitoSOX Red fluorescences were quantified from cells of interest using the measurement functions on the Carl Zeiss confocal software.

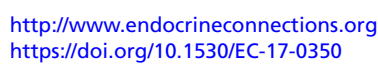

C) 2018 The authors Published by Bioscientifica Ltd
Detection of oxidative stress markers malondialdehyde (MDA) and superoxide dismutase (SOD)

The lipid peroxidation was determined by measuring the levels of malondialdehyde (MDA) using a Lipid Peroxidation (MDA) Colorimetric/Fluorometric Assay Kit (BioVision), according to the manufacturer's instructions. Total superoxide dismutase (SOD) activities were assessed using a SOD assay kit - WST (Dojindo, Kumamoto, Japan) following the manufacturer's instructions.

\section{Assay of mitochondrial enzyme activities}

Quantitative assays of the activities of specific mitochondrial enzymes, succinate dehydrogenase (SDH) and citrate synthase (CS) were performed in cell homogenates using Succinate Dehydrogenase Activity Colorimetric Assay Kit (BioVision) and Citrate Synthase Activity Colorimetric Assay Kit (BioVision), respectively, according to the manufacturer's instructions.

\section{Assessment of mitochondrial membrane potential $\left(\Delta \psi_{M}\right)$}

Mitochondrial membrane potential was assessed with the fluorescent dye JC-1 Mitochondrial Membrane Potential Detection kit (Stratagene) and confocal microscopy following the manufacturer's instructions. In brief, cells were incubated with $1 \times \mathrm{JC}-1$ reagent solution at $37^{\circ} \mathrm{C}$ for $15 \mathrm{~min}$. Culture slides were washed and mounted with PBS, and confocal images were acquired by the Carl Zeiss LSM 700 Meta confocal microscope. The redto-green fluorescence ratio was quantified from cells of interest using the measurement functions on the confocal microscopy software.

\section{Western blotting}

Cells were lysed in a buffer containing $20 \mathrm{mM}$ Tris- $\mathrm{HCl}$ (pH 7.4), $1 \mathrm{mM}$ EDTA, $140 \mathrm{mM} \mathrm{NaCl}, 1 \%$ (w/v) Nonidet P-40, $1 \mathrm{mM} \mathrm{Na}_{3} \mathrm{VO}_{4}, 1 \mathrm{mM}$ phenylmethylsulfonyl fluoride, $50 \mathrm{mM} \mathrm{NaF}$ and $10 \mu \mathrm{g} / \mathrm{mL}$ aprotinin. Cell lysates were separated by 8 or $12 \%$ SDS-PAGE and electrotransferred to a polyvinylidene difluoride membrane (Millipore). For the detection of Bax, Bcl-2 and cytochrome c, cells were fractionated into cytosol and mitochondria using a Mitochondria Isolation Kit (Thermo Fisher Scientific) according to the manufacturer's instructions. The membranes were soaked in blocking buffer

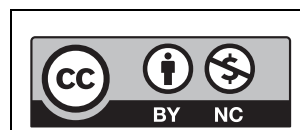

This work is licensed under a Creative Commons Attribution-NonCommercial 4.0 International License. 
(1× Tris-buffered saline, $0.1 \%$ Tween 20, 5\% nonfat dry milk) for $1 \mathrm{~h}$ and incubated overnight at $4^{\circ} \mathrm{C}$ with the primary antibody. Blots were developed using a peroxidase-conjugated anti-rabbit and anti-mouse IgG and a chemiluminescent detection system (Santa Cruz Biotechnology). The bands were visualized using a ChemiDoc XRS system (Bio-Rad) and quantified using Quantity One imaging software (Bio-Rad). The p-PDK1 (Ser241) and p-Akt (Thr 308 and Ser473) band intensities were normalized to PDK1 and Akt band intensities, respectively. The intensities of cleaved PARP were by the $\beta$-actin band intensity, the intensities of Bax were by COX IV intensities and the intensities of Bcl-2 and cytochrome c were adjusted by the intensities of $\alpha$-tubulin intensities.

\section{Statistical analysis}

Data are presented as the mean \pm s.E.M. ( $n=4 /$ treatment). Each experiment was repeated three times, giving essentially identical results. Statistical analysis between groups was performed using 1-way ANOVA and the Holm-Sidak method for multiple comparisons using SigmaStat for Windows, version 3.10 (Systat Software, Inc., Point Richmond, CA, USA). $P<0.05$ was considered statistically significant.

\section{Results}

\section{Effect of IGF-1 on MPP+-induced cytotoxicity}

To examine the effect of $\mathrm{MPP}^{+}$on SH-SY5Y cell viability, we treated cells with increasing concentrations of $\mathrm{MPP}^{+}$ for $24 \mathrm{~h}$. $\mathrm{MPP}^{+}$caused significant reduction in MTT values (Fig. 1A) and remarkable increase in LDH activity (Fig. 1C) in a concentration-dependent manner. A final concentration of $1 \mathrm{mM} \mathrm{MPP}{ }^{+}$was considered as an optimal concentration for the induction of cytotoxic effect on SH-SY5Y cells, and this dose was used for the rest of the experiments. In order to investigate whether IGF-1 may act as a survival factor for SH-SY5Y cells, we assayed the effect of IGF-1 on cell death induced by $\mathrm{MPP}^{+}$ insult. As shown in Fig. 1B, $\mathrm{MPP}^{+}$-induced cell death was partially but significantly attenuated by pretreatment of cells with $10 \mathrm{nM}$ IGF-1. The LDH activity assay showed that pretreatment of cells with IGF-1 suppressed $\mathrm{MPP}^{+}$-induced release of LDH (Fig. 1D). SH-SY5Y cells exposed to $\mathrm{MPP}^{+}$have been observed to undergo apoptosis $(9,10,11)$. Therefore, we investigated the effects of IGF-1 on $\mathrm{MPP}^{+}$-induced apoptosis in SH-SY5Y cells. The percentage of DNA fragmentation was significantly increased $\mathrm{MPP}^{+}$in a concentration-dependent manner (Fig. 1E). Pretreatment of cells with IGF-1 partially but

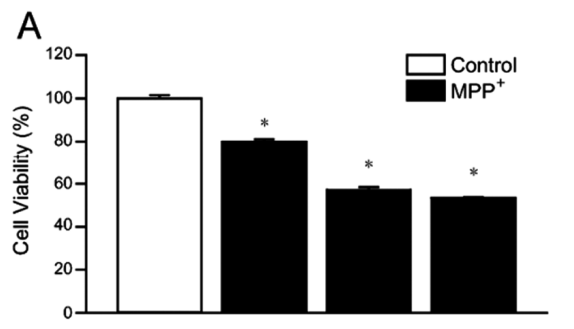

\section{B}
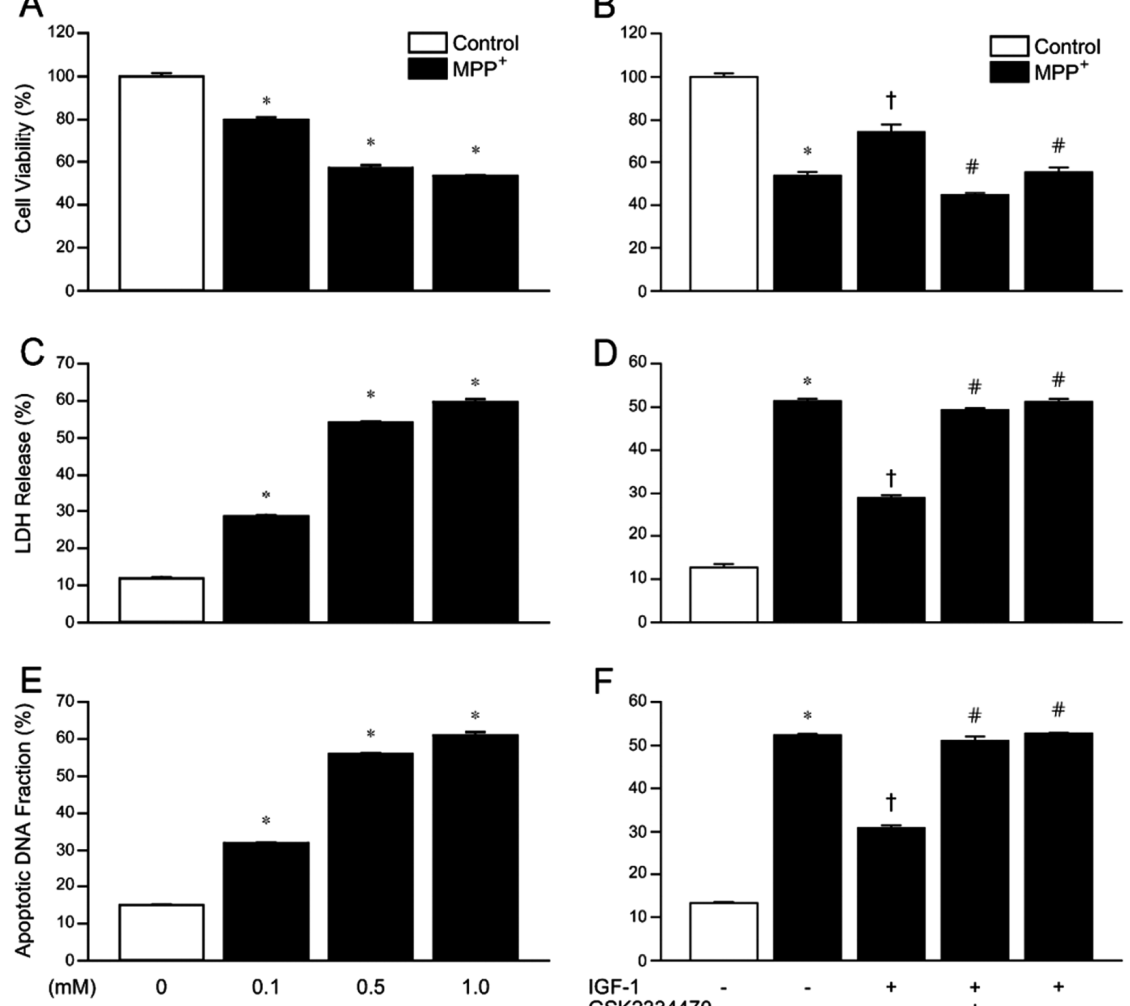

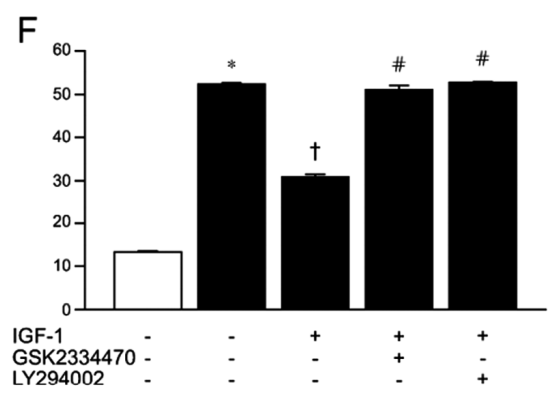

Figure 1

Effect of IGF-1 on MPP+-induced cytotoxicity. (A, C and $\mathrm{E}) \mathrm{SH}-\mathrm{SY} 5 \mathrm{Y}$ cells were treated with increasing concentration of $\mathrm{MPP}^{+}$for $24 \mathrm{~h}$. (B, D and F) Cells were pretreated with IGF-1 $(10 \mathrm{nM})$ for $1 \mathrm{~h}$ and then cells were exposed to $1 \mathrm{mM} \mathrm{MPP}^{+}$for $24 \mathrm{~h}$. ( $A$ and $B$ ) Cell viability measured by the MTT assay. (C and D) LDH release was assessed by the LDH assay kit. (E and F) DNA fragmentation, a marker of apoptosis, measured by ELISA. Values are mean \pm S.E.M. $(n=4)$. Each experiment was repeated twice. ${ }^{*} P<0.05$ vs vehicle-treated control and ${ }^{\dagger} P<0.05$ vs MPP ${ }^{+}$-treated cells.

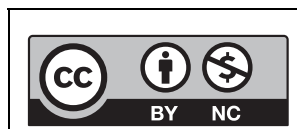

This work is licensed under a Creative Commons Attribution-NonCommercial 4.0 International License. 
significantly prevented apoptosis induced by $\mathrm{MPP}^{+}$ (Fig. 1F). The PI3K/PDK1/Akt pathway may be involved in the IGF-1-induced survival-promoting and anti-apoptotic effects in SH-SY5Y cells exposed to MPP+ insult. To further verify this hypothesis, we tested whether pretreatment of cells with the PDK1 inhibitor GSK2334470 or the PI3K inhibitor LY294002 impaired the effect of IGF-1 against $\mathrm{MPP}^{+}$. We found that all these inhibitors significantly blocked the survival-promoting (MTT assay and LDH release; Fig. 1B and D) and anti-apoptotic effects (DNA fragmentation; Fig. 1F) of IGF-1 on SH-SY5Y cells. These data suggest that IGF-1 inhibits apoptotic cell death induced by $\mathrm{MPP}^{+}$via the activation of PI3K/PDK1/Akt pathway.

\section{Effect of IGF-1 on Akt phosphorylation}

Next, we examined the effect of IGF-1 on Akt phosphorylation in SH-SY5Y cells. Treatment of cells with $10 \mathrm{nM}$ IGF-1 significantly increased phosphorylation of Akt at both Thr308 (Fig. 2A) and Ser478 (Fig. 2B), as previously reported (29). Since Akt is activated via the PI3K/PDK1 pathway (30), we further determined this signaling pathway was involved in IGF-1-induced Akt activation. We found that pretreatment of cells with the PDK1 inhibitor GSK2334470 or the PI3K inhibitor LY294002 significantly attenuated IGF-1-induced phosphorylation of Akt at both sites, suggesting that PI3K/PDK1 pathway contributes to IGF-1-induced activation of Akt.

\section{Effect of IGF-1 on MPP ${ }^{+}$-induced suppression of PDK1 and Akt phosphorylation}

$\mathrm{MPP}^{+}$is known to suppress the phosphorylation of Akt in SH-SY5Y cells $(18,31)$. Similar to this finding, the treatment of cells with $\mathrm{MPP}^{+}$decreased the levels of phosphorylated Akt at both residues after 24-h exposure of $\mathrm{MPP}^{+}$(Fig. 3A). In addition, we found that phosphorylated levels of PDK1 were also decreased by $\mathrm{MPP}^{+}$(Fig. 3B). In contrast, phosphorylated levels of Akt and PDK1 were significantly increased when cells were pretreated with IGF-1 (Fig. 3A and $\mathrm{B})$. Equal amounts of protein were confirmed by immunodetection of $\beta$-actin.

\section{Effect of IGF-1 on MPP+-induced oxidative stress}

To determine whether IGF-1 may inhibit $\mathrm{MPP}^{+}$-induced toxicity by suppression of ROS generation, we examined

$\begin{array}{lr}\text { http://www.endocrineconnections.org } & \text { ○ } 2018 \text { The authors } \\ \text { https://doi.org/10.1530/EC-17-0350 } & \text { Published by Bioscientifica Ltd }\end{array}$

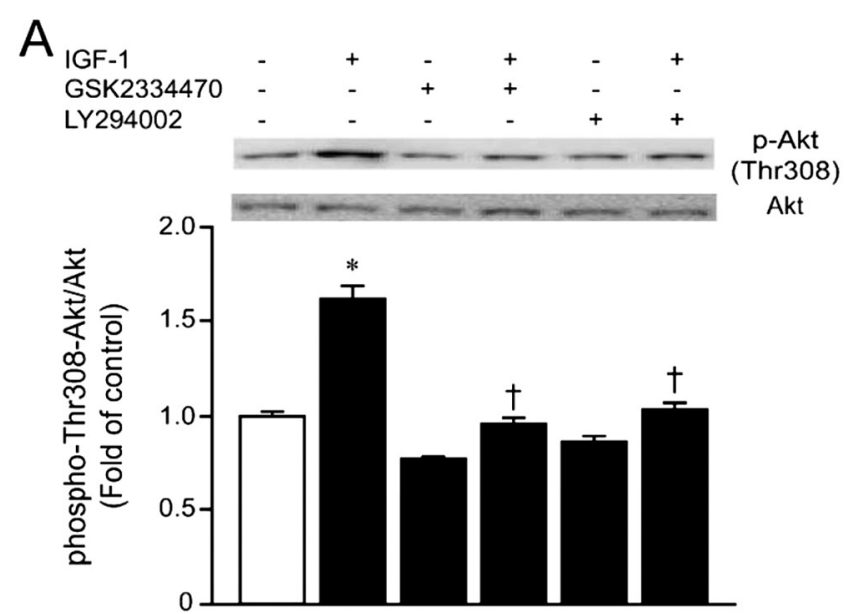

B

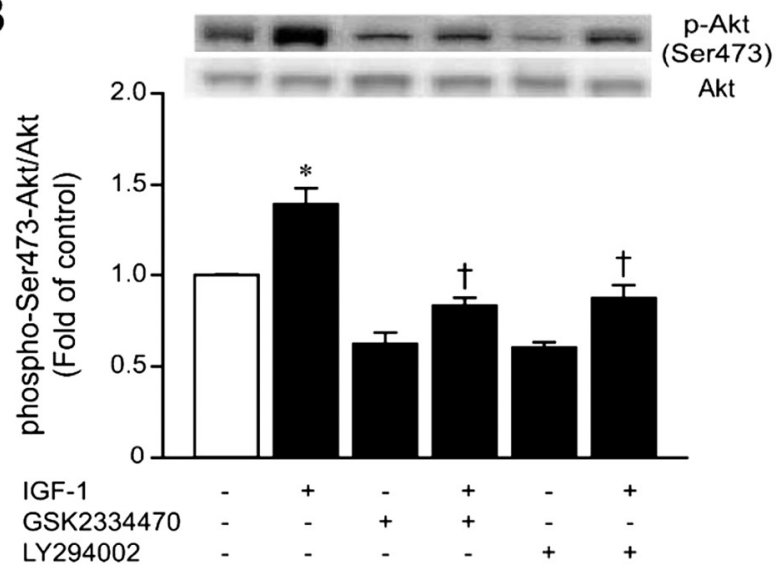

Figure 2

Effect of IGF-1 on Akt phosphorylation at Thr308 (A) and Ser478 (B). PI3K/PDK1 pathway mediates IGF-1-induced phosphorylation of Akt at both Thr308 and Ser478. Cells were preincubated with $2 \mu \mathrm{M}$ GSK2334470 or $4 \mu \mathrm{M}$ LY294002 for $30 \mathrm{~min}$, then treated with $10 \mathrm{nM}$ IGF-1 for $1 \mathrm{~h}$ and assayed by Western blotting as above. The phospho-Akt band intensity was normalized to Akt intensity and expressed as relative band intensity. Values are mean \pm S.E.M. $(n=4)$. Each experiment was repeated twice. $\star P<0.05$ vs control and ${ }^{\dagger} P<0.05$ vs IGF-1-treated cells.

the changes in intracellular ROS levels. As shown in Fig. 4A, compared with saline-treated controls, cells treated with $\mathrm{MPP}^{+}$showed increased cytosolic ROS production. In contrast, pretreatment of cells with IGF-1 significantly reduced the increase in DCF fluorescence induced by $\mathrm{MPP}^{+}$. MDA, one of the terminal products of polyunsaturated fatty acid peroxidation in cells, is used for lipid peroxidation. As shown in Fig. 4B, the levels of $\mathrm{MDA}$ in $\mathrm{MPP}^{+}$-treated cells were significantly increased than those of the vehicle-treated cells, indicating that $\mathrm{MPP}^{+}$induced an elevated oxidative stress in SH-SY5Y cells. By contrast, IGF-1 treatment significantly attenuated the increase in MDA levels induced by $\mathrm{MPP}^{+}$. To further examine the underlying mechanisms of the antioxidant

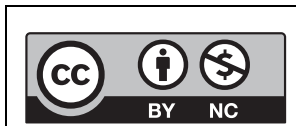

This work is licensed under a Creative Commons Attribution-NonCommercial 4.0 International License. 
A
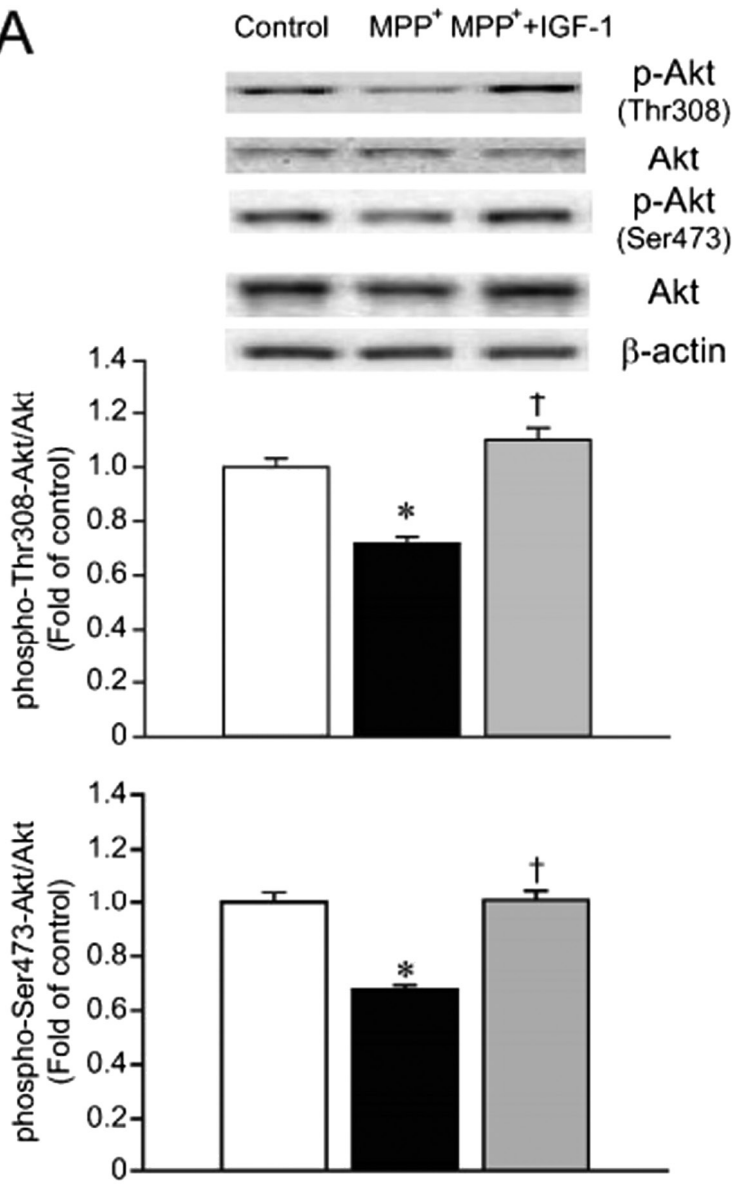

B

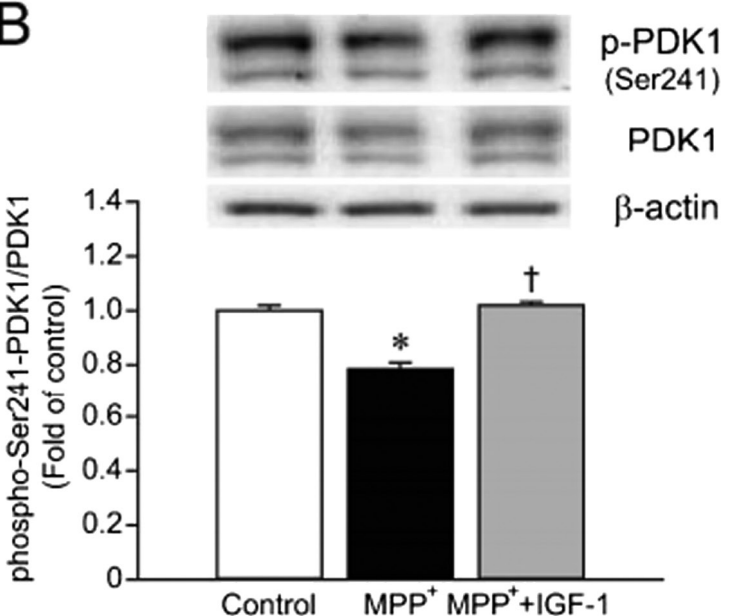

Figure 3

Effect of IGF-1 on MPP+-induced suppression of Akt and PDK1 phosphorylation. SH-SY5Y cells were pretreated with $10 \mathrm{nM}$ IGF-1 for $1 \mathrm{~h}$ Then cells were exposed to $1 \mathrm{mM} \mathrm{MPP}+$ for $24 \mathrm{~h}$. Protein lysates were prepared and assayed by Western blotting using specific anti-phosphoAkt (Thr308 and Ser473) and anti-Akt antibodies (A) or anti-phosphoPDK1 (Ser241) and anti-PDK1 antibodies (B). The band intensities of phospho-forms were normalized to the band intensities of total-forms respectively, and they were expressed as fold of control. Values are mean \pm S.E.M. $(n=4)$. Each experiment was repeated twice. ${ }^{*} P<0.05$ vs vehicle-treated control and ${ }^{\dagger} P<0.05$ vs MPP+-treated cells.

\begin{tabular}{lr}
\hline http://www.endocrineconnections.org & ○ 2018 The authors \\
https://doi.org/10.1530/EC-17-0350 & Published by Bioscientifica Ltd
\end{tabular}
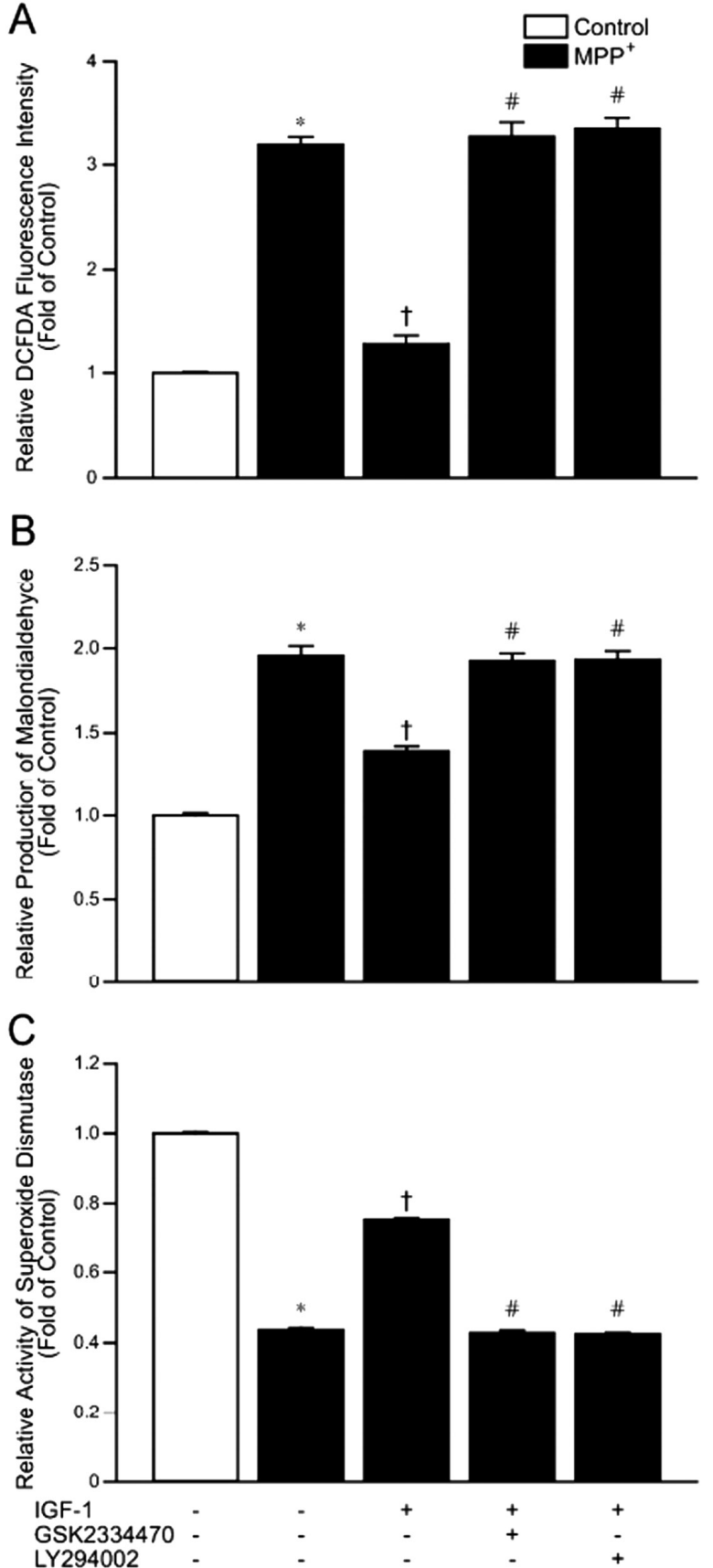

Figure 4

Effect of IGF-1 on MPP+-induced oxidative stress. SH-SY5Y cells were preincubated with $2 \mu \mathrm{M}$ GSK2334470 or $4 \mu \mathrm{M}$ LY294002 for $30 \mathrm{~min}$ and then treated with $10 \mathrm{nM} \mathrm{IGF-1}$ for $1 \mathrm{~h}$. Then, cells were exposed to $1 \mathrm{mM} \mathrm{MPP}+$ for $24 \mathrm{~h}$. (A) ROS levels were determined using confocal microscopy on cells stained with the ROS-sensitive fluorescent dye $2^{\prime}$ 7'-dichlorofluorescein diacetate (DCF-DA). DCF fluorescence was quantified from cells of interest using the measurement functions on the Carl Zeiss LSM 700 Meta software. The results are representatives of three independent experiments. (B) Malondialdehyde (MDA) levels were measured by thiobarbituric acid method using a MDA assay kit. (C) Superoxide dismutase (SOD) activities were assessed using a SOD assay kit. ${ }^{*} P<0.05$ vs vehicle-treated control, ${ }^{\dagger} P<0.05$ vs MPP+. insulted, vehicle-treated cells and ${ }^{\#} P<0.05$ vs MPP+-insulted, IGF-1-treated cells.

CC $\$$ NC $\begin{aligned} & \text { This work is licensed under a Creative Commons } \\ & \text { Attribution-NonCommercial } 4.0 \text { International } \\ & \text { License. }\end{aligned}$


properties of IGF-1 against $\mathrm{MPP}^{+}$insult, we assessed the activity of antioxidant enzyme SOD. We found that exposure of cells to $\mathrm{MPP}^{+}$resulted in a significant reduction of SOD activity, whereas IGF-1 prevented $\mathrm{MPP}^{+}$induced decrease in SOD activity (Fig. 4C). These results suggest that IGF-1 attenuated $\mathrm{MPP}^{+}$-induced oxidative stress by decreasing ROS production and MDA levels and increasing SOD activity. Moreover, pretreatment of cells with GSK2334470 or LY294002 significantly attenuated IGF-1-induced inhibition of intracellular ROS production and MDA levels in SH-SY5Y cells subjected to $\mathrm{MPP}^{+}$insult (Fig. 4A and B), suggesting the PI3K/PDK1/Akt pathway contributes to IGF-1-induced suppression of ROS levels and MDA contents. IGF-1-induced augmentation of SOD activity was also blocked when cells were pretreated with the PDK1 inhibitor or the PI3K inhibitor (Fig. 4C).

\section{Effect of IGF-1 on MPP ${ }^{+}$-induced mitochondrial dysfunction}

Next, we assessed mitochondrial ROS levels using MitoSOX Red as a mitochondrial superoxide indicator. Compared with vehicle-treated control, $\mathrm{MPP}^{+}$increased mitochondrial ROS levels, whereas IGF-1 significantly reduced the increase in MitoSOX Red fluorescence induced by $\mathrm{MPP}^{+}$(Fig. 5A). IGF-1 failed to inhibit $\mathrm{MPP}^{+}$- induced increase in mitochondrial ROS levels when cells were pretreated with GSK2334470 or LY294002. Next, we measured the activities of key enzymes in the Krebs cycle pathway, SDH and CS. We found a robust reduction in the activity of SDH and modest diminution in the CS activity in the $\mathrm{MPP}^{+}$-treated cells (Fig. 5B and C). In contrast, IGF-1 treatment significantly attenuated the inhibitory effect of $\mathrm{MPP}^{+}$on citric acid cycle enzymes. The attenuating effect of IGF-1 on $\mathrm{MPP}^{+}$-induced suppression of SDH and CS activities was abolished when cells were pretreated with GSK 2334470 or LY294002 (Fig. 5C and D). It has been reported that $\mathrm{MPP}^{+}$destabilizes $\Delta \psi_{\mathrm{M}}$ due to the opening of the mitochondrial permeability transition (PT) pore $(32,33)$, and IGF-1 attenuates apoptosis by preventing mitochondrial depolarization $(34,35)$. Therefore, we examined the effect of IGF-1 on $\Delta \psi_{\mathrm{M}}$ using JC-1, which exhibits potential-dependent accumulation in the mitochondria. As shown in Fig. 5D, it was observed that $\Delta \psi_{\mathrm{M}}$ was significantly decreased as indicated by the marked decreases in red/green fluorescence intensity ratio when cells were exposed to $\mathrm{MPP}^{+}$. In contrast, pretreatment of cells with IGF-1 partially but significantly attenuated the $\mathrm{MPP}^{+}$-induced decrease in the ratio (Fig. 5D). Moreover, the mitochondrial membrane-stabilizing effect of IGF-1 was inhibited by the pretreatment of cells with GSK2334470 or LY294002 (Fig. 5D).
A
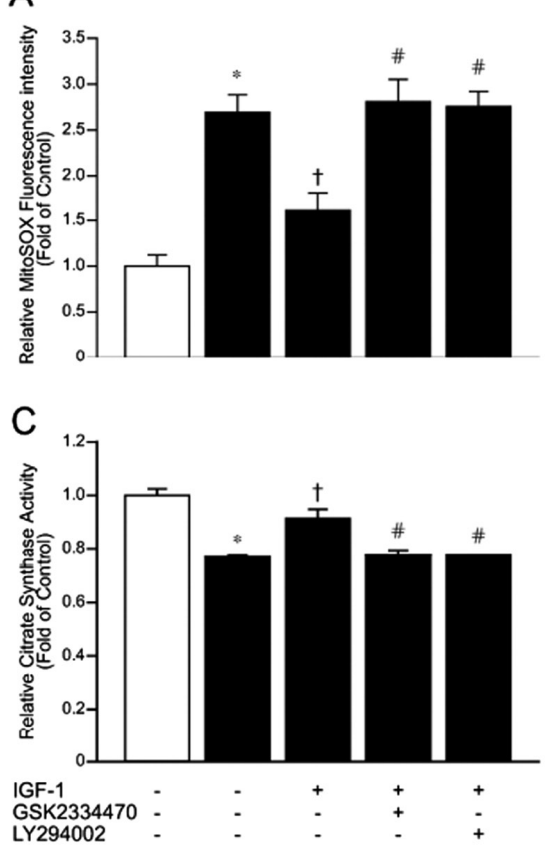

B

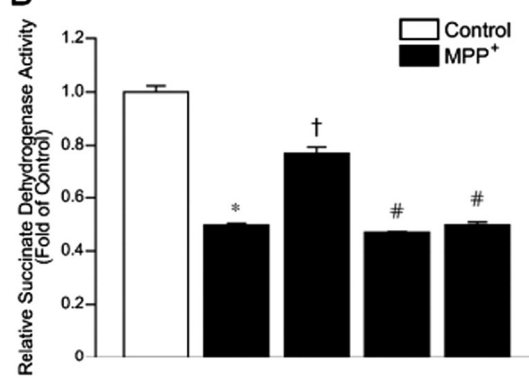

D

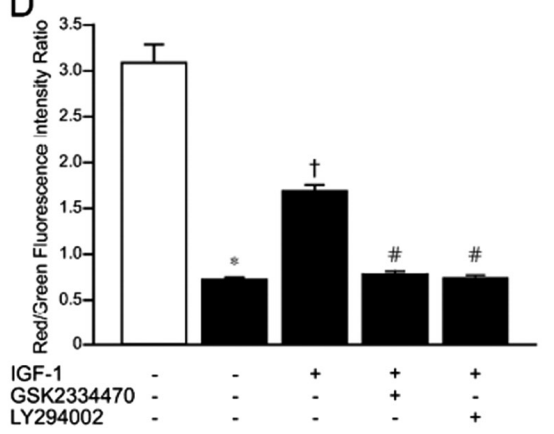

Figure 5

Effect of IGF-1 on MPP+-induced mitochondrial dysfunction. SH-SY5Y cells were preincubated with $2 \mu \mathrm{M}$ GSK2334470 or $4 \mu \mathrm{M}$ LY294002 for $30 \mathrm{~min}$ and then treated with $10 \mathrm{nM}$ IGF- 1 for $1 \mathrm{~h}$ Then, cells were exposed to $1 \mathrm{mM} \mathrm{MPP}^{+}$for $24 \mathrm{~h}$. (A) Mitochondrial ROS levels were determined using confocal microscopy on cells stained with MitoSOX Red, a mitochondrial superoxide indicator. MitoSOX Red fluorescence was quantified from cells of interest using the measurement functions on the Carl Zeiss LSM 700 Meta software. (B) Succinate dehydrogenase (SDH) activity was assessed by measuring 2,6-dichlorophenol-indophenol-dependent reduction by succinate using a SDH assay kit. (C) Citrate synthase (CS) activity was assessed by measuring the conversion rate of 5,5'-dithiobis-(2nitrobenzoic acid) to 2-nitro-5-thiobenzoate in the presence of oxaloacetate and acetyl-CoA using a CS assay kit. (D) The $\Delta \psi_{\mathrm{M}}$ was determined by confocal microscopy using JC-1 dye. The ratio of red-to-green fluorescence was quantified in cells of interest using the measurement functions on the Carl Zeiss LSM 700 Meta software. ${ }^{*} P<0.05$ vs vehicle-treated control, ${ }^{\dagger} P<0.05$ vs $\mathrm{MPP}^{+}-$ insulted, vehicle-treated cells and ${ }^{\#} P<0.05$ vs $\mathrm{MPP}^{+}$-insulted, IGF-1-treated cells.

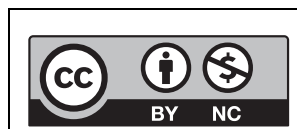

This work is licensed under a Creative Commons Attribution-NonCommercial 4.0 International License. 


\section{Effect of IGF-1 on MPP ${ }^{+}$-induced apoptosis at the mitochondrial level}

To examine changes in the protein levels of Bax, we performed Western blots using cytosolic and mitochondrial fractions and found that $\mathrm{MPP}^{+}$increased Bax protein in the mitochondrial fraction of cells (Fig. 6A), suggesting a translocation from the cytosol to the mitochondria. IGF-1 significantly inhibited the $\mathrm{MPP}^{+}$-induced increase in Bax protein in the mitochondria (Fig. 6A). We also investigated the levels of Bcl-2 protein in the cytosol and found that Bcl-2 protein levels were decreased by $\mathrm{MPP}^{+}$, whereas IGF-1 treatment increased Bcl-2 (Fig. 6A), thereby significantly increasing the Bcl-2/Bax ratio (Fig. 6B). Additionally, IGF-1 failed to increase the ratio of Bcl-2/Bax when cells were pretreated with the PDK1 inhibitor or PI3K inhibitor (Fig. 6B). To investigate whether IGF-1 inhibits $\mathrm{MPP}^{+}$-induced release of cytochrome c, Western blots were carried out on cytosolic and mitochondrial fractions of SH-SY5Y cells. As shown in Fig. 6A and C, exposure of cells to $\mathrm{MPP}^{+}$resulted in the release of cytochrome $\mathrm{c}$ from the mitochondria to the cytosol, which was significantly reduced by pretreatment with IGF-1. COX IV was detected in mitochondrial fractions but not in the cytosolic fractions (Fig. 6A). Then, we examined whether $\mathrm{MPP}^{+}$ induces activation of caspase- 3 and found that $\mathrm{MPP}^{+}$ exposure resulted in an increase in protein levels of active caspase-3 (Fig. 6D). By contrast, IGF-1 significantly reduced $\mathrm{MPP}^{+}$-induced augmentation in active caspase- 3 protein levels (Fig. 6D). We further investigated the effect of IGF-1 on $\mathrm{MPP}^{+}$-induced apoptosis by the evidence of cleavage of PARP and found that IGF-1 significantly attenuated PARP cleavage when cells were exposed to $\mathrm{MPP}^{+}$(Fig. 6E). In addition, the pathways mediating the IGF-1-induced inhibition of cytochrome c release, caspase- 3 activation and PARP cleavage were examined by exposure of cells to GSK2334470 or LY294002. As shown in Fig. 6C, D and E, these inhibitors attenuated the release of cytochrome c, activation of caspase- 3 and cleavage of PARP.

\section{Discussion}

IGF-1 is a well-known anti-apoptotic/pro-survival factor for neuronal cells in various in vitro models of neurodegenerative diseases. In the current study, our results demonstrate that IGF-1 treatment reduces apoptotic cell death caused by MPP+ insult in SH-SY5Y cells as evidenced by the enhanced cell viability and the decreased apoptosis. Phosphorylated levels of PDK1 and Akt were significantly reduced after exposure to $\mathrm{MPP}^{+}$, while pretreatment of

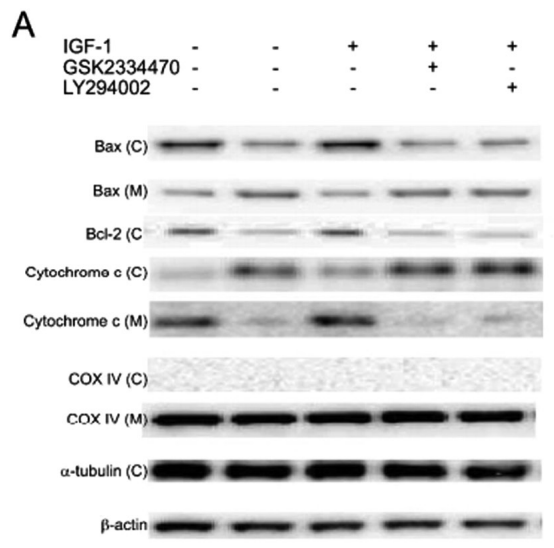

D

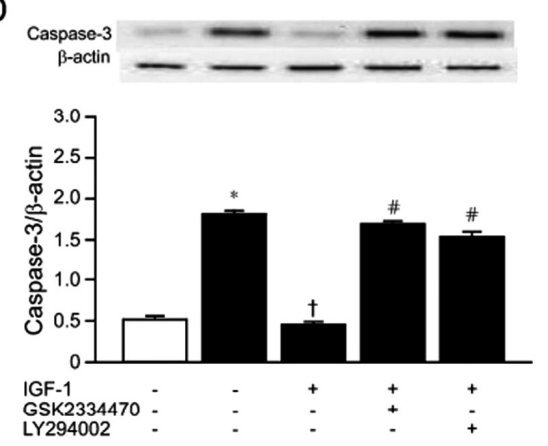

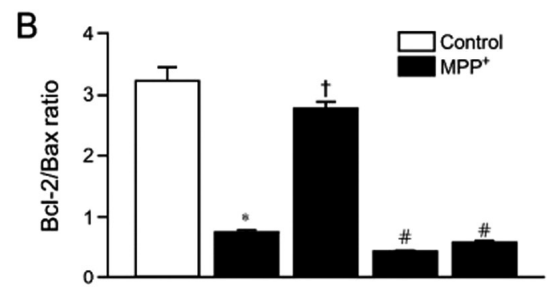

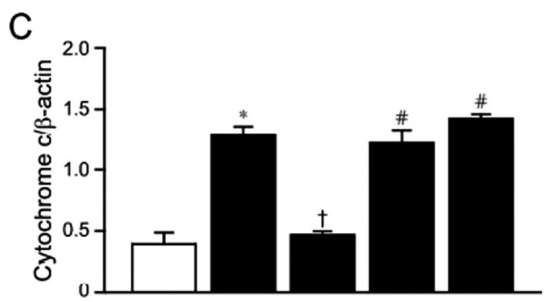

E
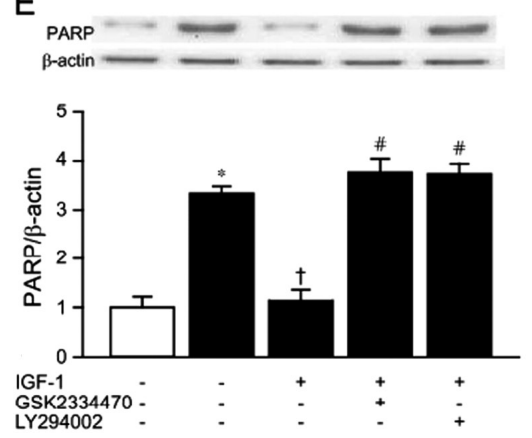

Figure 6

Effect of IGF-1 on protein levels of Bax, $\mathrm{Bcl}-2$, cytochrome c, active caspase- 3 and PARP in cells exposed to MPP+. SH-SY5Y cells were preincubated with $2 \mu \mathrm{M}$ GSK2334470 or $4 \mu \mathrm{M}$ LY294002 for $30 \mathrm{~min}$ and then treated with $10 \mathrm{nM}$ IGF-1 for $1 \mathrm{~h}$. Then, cells were exposed to $1 \mathrm{mM}$ $\mathrm{MPP}^{+}$for $24 \mathrm{~h}$. (A) Representative Western blot images of Bax in the cytosolic and mitochondrial fraction, $\mathrm{Bcl}-2$ in the cytosolic fraction, cytochrome $\mathrm{c}$ in the cytosolic and mitochondrial fraction, COX IV in the cytosolic and mitochondrial fraction, $\alpha$-tubulin in the cytosolic fraction and $\beta$-actin are shown. ( $B$ and $C$ ) Bar graphs show the ratio of protein levels of $\mathrm{BCl}-2$ to Bax (B) and cytochrome c protein levels in the cytosolic fraction (C). (D) Representative Western blot images of active caspase- 3 are shown in the upper insets. Bar graphs show the protein levels of active caspse-3. (E) Representative Western blot images of PARP are shown in the upper insets. Bar graphs show the protein levels of PARP. * $P<0.05$ vs vehicle-treated control, ${ }^{\dagger} P<0.05$ vs MPP+-insulted, vehicle-treated cells and ${ }^{\#} P<0.05$ vs MPP+-insulted, IGF-1-treated cells. http://www.endocrineconnections.org https://doi.org/10.1530/EC-17-0350
(C) 2018 The authors Published by Bioscientifica Ltd

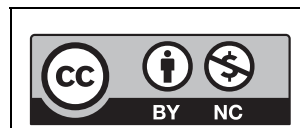

This work is licensed under a Creative Commons Attribution-NonCommercial 4.0 International License. 
cells with IGF-1 completely prevented $\mathrm{MPP}^{+}$-induced reductions in phosphorylation. We showed that IGF-1 suppresses oxidative stress and attenuates mitochondrial dysfunction induced by $\mathrm{MPP}^{+}$. In addition, we present evidence that IGF-1 alters the status of the Bcl-2 family of proteins, inhibiting cytochrome c release, caspase- 3 activity, PARP cleavage and promoting the survival of SH-SY5Y cells exposed to $\mathrm{MPP}^{+}$. The protective effect of IGF-1 against $\mathrm{MPP}^{+}$insult appears to be mediated through the activation of PI3K/PDK1/Akt signaling pathway.

It has been demonstrated that IGF-1 promotes differentiation and proliferation and sustains survival, preventing apoptosis of neuronal cells (36). The ability of IGF-1 to augment neuronal survival is associated with its apoptosis-inhibiting effect. In the current study, we found that IGF-1 prevented $\mathrm{MPP}^{+}$-induced cell death by inhibiting apoptosis. This observation is similar to the report of Sun et al. (25) and Wang et al. (26), where IGF-1 rescued PC12 and SH-EP1 cells from $\mathrm{MPP}^{+}$-induced apoptosis via the activation of Akt/glycogen synthase kinase-3 pathway. Binding of IGF-1 to its corresponding receptor results in the activation of the PI3K/Akt pathway, one of the main IGF-1R signaling cascades (14). We have shown that the protective effect of IGF-1 is mediated by the activation of the PI3K/Akt pathway because the PI3K inhibitor LY294002 blocked IGF-1-induced phosphorylation of Akt and the protective effect of IGF-1 against $\mathrm{MPP}^{+}$insult, similar to previous papers demonstrating that IGF-1 inhibits apoptosis through the activation of this signaling pathway $(37,38,39)$. In order to determine the upstream signaling event leading to Akt activation in the IGF-1treated SH-SY5Y cells, we examined the phosphorylation of Akt and found that IGF-1 led to a potent and sustained activation of Akt. Upstream kinases, such as PI3K, mammalian target of rapamycin complex, and PDK1 modulate Akt signaling. Previous studies suggested that PDK1 is required for Akt-induced inhibition of apoptosis $(40,41)$. In the current study, the highly potent and selective PDK1 inhibitor GSK2334470 significantly suppressed IGF-1-induced phosphorylation of Akt and the anti-apoptotic effect of IGF-1. Furthermore, IGF-1induced attenuation of oxidative stress and restoration of mitochondrial function were inhibited when cells were pretreated with GSK2334470 or LY294002. These data suggest that PI3K/PDK1 pathway is involved in IGF-1-induced Akt activation, and the survival-promoting effect of IGF-1 is mediated via PI3K/PDK1/Akt signaling pathway.

It has been reported that Akt and phosphorylated Akt-containing SNpc dopaminergic neurons are severely depleted in the brain in PD obtained at autopsy (17). The selective loss of Akt activity was also observed in ventral midbrain of mice treated with MPTP (16). Moreover, Akt phosphorylation was decreased when SH-SY5Y cells were exposed to $\mathrm{MPP}^{+}(18,31)$. Considering that Akt is a critical molecule for neuronal survival and Akt signaling is impaired in $\mathrm{PD}$, the molecules activating PI3K/Akt pathway may have pro-survival potential. In the present study, we have shown that exposure of cells to $\mathrm{MPP}^{+}$ significantly reduced the levels of Akt phosphorylation, similar to the previous reports $(18,31)$, suggesting a role of impaired Akt phosphorylation in $\mathrm{MPP}^{+}$-induced apoptosis in SH-SY5Y cells. IGF-1 completely prevented this reduction of Akt phosphorylation induced by $\mathrm{MPP}^{+}$insult. The stimulatory effect of IGF-1 on Akt phosphorylation may contribute to maintaining the PI3K/Akt signaling pathway and resulting in the promotion of cell survival. Next, we further examined the levels of phosphorylation of PDK1 and found significantly reduced levels of phosphorylation in $\mathrm{MPP}^{+}$-treated cells. This finding suggests that the mechanisms underlying $\mathrm{MPP}^{+}$ induced apoptosis may include impairment in the activity of the PI3K/PDK1 pathway. To the best of our knowledge, this is the first report demonstrating the downregulation of PDK1 phosphorylation induced by $\mathrm{MPP}^{+}$. In this study, we also found that IGF-1 completely restored $\mathrm{MPP}^{+}$induced reduction of PDK1 phosphorylation, suggesting that PI3K/PDK1 pathway could be linked to antiapoptotic effect of IGF-1. In this regard, we propose that the ability of IGF-1 to prevent $\mathrm{MPP}^{+}$-induced reduction in PI3K/PDK1/Akt signaling pathway plays an important role in its protective effect in this experimental PD model.

Oxidative stress is known to play an important role in apoptosis after $\mathrm{MPP}^{+}$exposure (32). In order to investigate the balance between oxidation and antioxidation in $\mathrm{MPP}^{+}$-treated cells, we measured MDA levels and SOD activity. In agreement with previous reports $(42,43), \mathrm{MPP}^{+}$ caused an increase in MDA levels and a decrease in SOD activity suggesting the disbalance of lipid peroxidation and antioxidant protection system. However, this $\mathrm{MPP}^{+}$induced imbalance was attenuated by IGF-1 treatment. Our data suggest that IGF-1 mitigated oxidative damage system and augmented antioxidative defense system by decreasing MDA contents and increasing the activity of SOD. In the present study, we have shown that IGF-1 treatment prevents $\mathrm{MPP}^{+}$-induced ROS generation. Because ROS play a role in early and late steps of the regulation of apoptosis (44), the capability of IGF-1 to decrease ROS production seems to be important for its protective mechanisms against $\mathrm{MPP}^{+}$cytotoxicity. Indeed, 
IGF-1 is shown to reduce oxidative stress $(39,45,46,47)$. The anti-apoptotic protein $\mathrm{Bcl}-2$ is a reasonable target for the putative antioxidant capacity of IGF-1 because IGF-1 induces Bcl-2 (48), and it has been shown that Bcl-2 can protect cells from apoptosis by preventing ROS accumulation (49). Therefore, we consider that the increased Bcl-2 protein levels in IGF-1-treated cells may both promote cell survival and protect against $\mathrm{MPP}^{+}$-induced oxidative stress.

It has been suggested that mitochondria are an important source of cytosolic ROS $(50,51)$ and increases in mitochondrial ROS generation induce cellular oxidative damage and tissue dysfunction (52). $\mathrm{MPP}^{+}$can be concentrated in mitochondria of dopaminergic neurons, where it blocks the mitochondrial electron transport chain complex I, resulting in the enhanced ROS generation, decreased ATP synthesis and subsequent cell death (5). We therefore examined if $\mathrm{MPP}^{+}$exposure increased mitochondrial ROS levels and found that mitochondriaderived superoxide production was significantly increased during $\mathrm{MPP}^{+}$exposure, as previously reported (53), and this accumulation of mitochondrial ROS was significantly attenuated by IGF-1 treatment. Similar findings were observed in striatal cells, in which IGF-1 decreased mitochondrial ROS induced by mutant hungtingtin (22). Next, we wanted to identify the effects of IGF-1 on mitochondrial bioenergetic function and mitochondrial integrity by investigating the activity of key mitochondrial enzymes in the citric acid cycle, SDH and CS. SDH, also known as mitochondrial complex II, plays a critical role in cellular oxidative phosphorylation and is associated with oxidative stress. Given that the activity of $\mathrm{SDH}$ was decreased in PD patients (54) and dysfunction or inhibition of the SDH can cause mitochondrial dysfunction and interruption of ATP production (55), SDH could be regarded as one of the main regulators in neuroprotection in PD. As one of the gatekeepers of the Krebs cycle, CS plays an important role in regulating the energy flux and metabolic rate of the cell. Impaired activity of CS is known to interfere mitochondrial function and aggravate agerelated hearing loss (56) and IGF-1 maintains CS activity in myocytes following hypoxia/reoxygenation stress (47). In this study, the activities of SDH and CS were also decreased by $\mathrm{MPP}^{+}$. In contrast, in IGF-1-treated SH-SY5Y cells, the activities of SDH and CS were increased, indicating that IGF-1 is capable of preventing dysfunction of the citric acid cycle and mitochondrial oxidative system in SH-SY5Y cells exposed to $\mathrm{MPP}^{+}$.

http://www.endocrineconnections.org https://doi.org/10.1530/EC-17-0350

(c) 2018 The authors Published by Bioscientifica Ltd
$\mathrm{MPP}^{+}$-induced oxidative stress leads to the opening of mitochondrial PT pore, through which cytochrome $\mathrm{c}$ is released from mitochondrial inter-membrane space prior to caspase activation (57). The mitochondrial PT pore is regulated by the Bcl-2 family proteins, such as Bcl-2 and $\operatorname{Bax}(58,59,60)$. The Bcl-2 protein prevents apoptosis by maintaining the $\Delta \psi_{\mathrm{M}}$ and blocking the release of cytochrome c, whereas the Bax protein stimulates apoptosis by collapsing the $\Delta \psi_{\mathrm{M}}$, leading to increased cytochrome c release. Indeed, we found that $\mathrm{MPP}^{+}$caused a significant decrease in the level of Bcl-2 and a significant increase in the level of Bax, thereby decreasing the ratio of Bcl-2 to Bax. In contrast, IGF-1 increased Bcl-2 and decreased Bax levels in $\mathrm{MPP}^{+}$-treated cells. Bax is mainly distributed in the cytoplasm in healthy cells but activated Bax is translocated to the mitochondrial outer membrane under apoptotic stimuli, such as $\operatorname{MPP}^{+}(9,42,43)$. Our results showed that Bax was moved from the cytoplasm to the mitochondria by $\mathrm{MPP}^{+}$insult while IGF-1 treatment completely restored the $\mathrm{MPP}^{+}$-induced translocation of Bax. In this study, we also observed that IGF-1 prevented $\mathrm{MPP}^{+}$-induced mitochondrial membrane depolarization, suggesting that IGF-1 may inhibit mitochondrial PT pore opening in SH-SY5Y cells exposed to $\mathrm{MPP}^{+}$. Taken together, these results suggest that IGF- 1 stabilizes the $\Delta \psi_{\mathrm{M}}$ by regulating Bcl-2 family proteins during $\mathrm{MPP}^{+}$exposure and by that, preventing the activation of mitochondrial apoptotic cascades.

In this study, translocation of cytochrome c from mitochondria into the cytoplasm was observed when cells were exposed to $\mathrm{MPP}^{+}$, as previously reported (61). Apoptosis can be prevented by suppressing cytochrome c release because transport of cytochrome c to the cytoplasm is needed for the initiation of mitochondrial apoptotic cascades $(58,59)$. Upon released, cytochrome c forms the apoptosome, a complex composed of apoptosisactivating factor Apaf-1, procaspase-9 and adenosine triphosphate, leading to the activation of caspase- 9 and caspase- 3 with PARP cleavage and resulting in apoptosis $(58,59)$. It has been reported that IGF-1 exerts its antiapoptotic effects on SH-SY5Y cells exposed to proteasome inhibitor epoxomicin by preventing cytochrome c release, inhibiting caspase-3 activation and suppressing PARP cleavage (62). In agreement with these findings, in the current study, IGF-1 prevented the $\mathrm{MPP}^{+}$-induced release of cytochrome c and subsequent activation of caspase-3 with PARP cleavage, thus inhibiting activation of the apoptotic pathway. 
In conclusion, our findings indicate that IGF-1 is a powerful survival factor that protects SH-SY5Y cells from oxidative stress-mediated apoptosis induced by $\mathrm{MPP}^{+}$by reducing mitochondrial dysfunction. Specifically, the protective mechanism of IGF-1 involves preserving the activity of the key enzymes in the Krebs cycle, stabilizing the $\Delta \psi_{\mathrm{M}}$, increasing the ratio of Bcl-2 to Bax, maintaining the mitochondrial retention of cytochrome $c$ and reducing activation of caspase- 3 with PARP cleavage. Our data also show that the effects of IGF-1 seem to be mediated by the activation of PI3K/PDK1/Akt pathway. IGF-1 is likely to represent a plausible therapeutic target for the treatment of neurodegenerative disorders including PD.

\section{Declaration of interest}

The authors declare that there is no conflict of interest that could be perceived as prejudicing the impartiality of the research reported.

\section{Funding}

This research was supported by the National Research Foundation of Korea (NRF) grant funded by the Korea government (MSIP) (No. 2011-0030072).

\section{Author contribution statement}

Chanyang Kim carried out the laboratory experiments. Seungjoon Park designed the study, analyzed and interpreted the data and wrote the manuscript.

\section{References}

1 Tanner CM \& Goldman SM. Epidemiology of Parkinson's disease. Neurologic Clinics 199614 317-335.

2 Langston JW. Parkinson's disease: current and future challenges. Neurotoxicology 200223 443-450. (https://doi.org/10.1016/S0161813X(02)00098-0)

3 Ghavami S, Shojaei S, Yeganeh B, Ande SR, Jangamreddy JR, Mehrpour M, Christoffersson J, Chaabane W, Moghadam AR, Kashani $\mathrm{HH}$, et al. Autophagy and apoptosis dysfunction in neurodegenerative disorders. Progress in Neurobiology 2014112 24-49.

4 Onyango IG. Mitochondrial dysfunction and oxidative stress in Parkinson's disease. Neurochemical Research 200833 589-597. (https://doi.org/10.1007/s11064-007-9482-y)

5 Tipton KF \&Singer TP. Advances in our understanding of the mechanisms of the neurotoxicity of MPTP and related compounds. Journal of Neurochemistry 199361 1191-1206. (https://doi. org/10.1111/j.1471-4159.1993.tb13610.x)

6 Zeissler ML, Eastwood J, McCorry K, Hanemann CO, Zajicek JP \& Carroll CB. Delta-9-tetrahydrocannabinol protects against $\mathrm{MPP}+$ toxicity in SH-SY5Y cells by restoring proteins involved in mitochondrial biogenesis. Oncotarget 20167 46603-46614.

7 Kujoth GC, Hiona A, Pugh TD, Someya S, Panzer K, Wohlgemuth SE, Hofer T, Seo AY, Sullivan R, Jobling WA, et al. Mitochondrial DNA mutations, oxidative stress, and apoptosis in mammalian aging. Science 2005309 481-484. (https://doi.org/10.1126/ science.1112125)

8 Yoshida H, Kong YY, Yoshida R, Elia AJ, Hakem A, Hakem R, Penninger JM \& Mak TW. Apaf1 is required for mitochondrial pathways of apoptosis and brain development. Cell $1998 \mathbf{9 4}$ 739-750. (https://doi.org/10.1016/S0092-8674(00)81733-X) 9 Oh Y, Jeong K, Kim K, Lee YS, Jeong S, Kim SS, Yoon KS, Ha J, Kang I \& Choe W. Cyclophilin B protects SH-SY5Y human neuroblastoma cells against MPP(+)-induced neurotoxicity via JNK pathway. Biochemical and Biophysical Research Communications 2016478 1396-1402. (https://doi.org/10.1016/j.bbrc.2016.08.135)

10 Martins JB, Bastos MeL, Carvalho F \& Capela JP. Differential effects of methyl-4-phenylpyridinium ion, rotenone, and paraquat on differentiated SH-SY5Y cells. Journal of Toxicology 20132013347312.

11 Wu F, Poon WS, Lu G, Wang A, Meng H, Feng L, Li Z \& Liu S. Alphasynuclein knockdown attenuates MPP+ induced mitochondrial dysfunction of SH-SY5Y cells. Brain Research 20091292 173-179. (https://doi.org/10.1016/j.brainres.2009.07.067)

12 Feldman EL, Sullivan KA, Kim B \& Russell JW. Insulin-like growth factors regulate neuronal differentiation and survival. Neurobiology of Disease 19974 201-214.

13 LeRoith D, Werner H, Beitner-Johnson D \& Roberts CT Jr. Molecular and cellular aspects of the insulin-like growth factor I receptor. Endocrine Reviews 199516 143-163.

14 Kooijman R. Regulation of apoptosis by insulin-like growth factor (IGF)-I. Cytokine and Growth Factor Reviews 200617 305-323. (https:// doi.org/10.1016/j.cytogfr.2006.02.002)

15 Datta SR, Brunet A \& Greenberg ME. Cellular survival: a play in three Akts. Genes and Development 199913 2905-2927. (https://doi. org/10.1101/gad.13.22.2905)

16 Durgadoss L, Nidadavolu P, Valli RK, Saeed U, Mishra M, Seth P \& Ravindranath V. Redox modification of Akt mediated by the dopaminergic neurotoxin MPTP, in mouse midbrain, leads to downregulation of pAkt. FASEB Journal 201226 1473-1483. (https://doi. org/10.1096/fj.11-194100)

17 Timmons S, Coakley MF, Moloney AM \& O’ Neill NC. Akt signal transduction dysfunction in Parkinson's disease. Neuroscience Letters 2009467 30-35.

18 Tasaki Y, Omura T, Yamada T, Ohkubo T, Suno M, Iida S, Sakaguchi T, Asari M, Shimizu K \& Matsubara K. Meloxicam protects cell damage from 1-methyl-4-phenyl pyridinium toxicity via the phosphatidylinositol 3-kinase/Akt pathway in human dopaminergic neuroblastoma SH-SY5Y cells. Brain Research 20101344 25-33. (https://doi.org/10.1016/j.brainres.2010.04.085)

19 Manning BD \& Cantley LC. AKT/PKB signaling: navigating downstream. Cell 2007129 1261-1274. (https://doi.org/10.1016/j. cell.2007.06.009)

20 Sarbassov DD, Guertin DA, Ali SM \& Sabatini DM. Phosphorylation and regulation of Akt/PKB by the rictor-mTOR complex. Science 2005 307 1098-1101. (https://doi.org/10.1126/science.1106148)

$21 \mathrm{Li}$ Y, Shelat H \& Geng YJ. IGF-1 prevents oxidative stress inducedapoptosis in induced pluripotent stem cells which is mediated by microRNA-1. Biochemical and Biophysical Research Communications 2012426 615-619. (https://doi.org/10.1016/j.bbrc.2012.08.139)

22 Ribeiro M, Rosenstock TR, Oliveira AM, Oliveira CR \& Rego AC. Insulin and IGF-1 improve mitochondrial function in a PI-3K/ Akt-dependent manner and reduce mitochondrial generation of reactive oxygen species in Huntington's disease knock-in striatal cells. Free Radical Biology and Medicine 201474 129-144. (https://doi. org/10.1016/j.freeradbiomed.2014.06.023)

23 Quesada A, Romeo HE \& Micevych P. Distribution and localization patterns of estrogen receptor-beta and insulin-like growth factor-1 receptors in neurons and glial cells of the female rat substantia nigra: localization of ERbeta and IGF-1R in substantia nigra. Journal of Comparative Neurology 2007503 198-208. (https://doi.org/10.1002/ cne.21358)

24 Nadjar A, Berton O, Guo S, Leneuve P, Dovero S, Diguet E, Tison F, Zhao B, Holzenberger M \& Bezard E. IGF-1 signaling reduces neuro-inflammatory response and sensitivity of neurons to MPTP. Neurobiology of Aging 200930 2021-2030. http://www.endocrineconnections.org https://doi.org/10.1530/EC-17-0350 (c) 2018 The authors Published by Bioscientifica Ltd
This work is licensed under a Creative Commons Attribution-NonCommercial 4.0 International License. 
25 Sun X, Huang L, Zhang M, Sun S \& Wu Y. Insulin like growth factor-1 prevents 1-mentyl-4-phenylphyridinium-induced apoptosis in PC12 cells through activation of glycogen synthase kinase-3beta. Toxicology 2010271 5-12. (https://doi.org/10.1016/j.tox.2010.01.001)

26 Wang L, Yang HJ, Xia YY \& Feng ZW. Insulin-like growth factor 1 protects human neuroblastoma cells SH-EP1 against MPP+-induced apoptosis by AKT/GSK-3beta/JNK signaling. Apoptosis 201015 1470-1479. (https://doi.org/10.1007/s10495-010-0547-z)

27 Kim Y, Li E \& Park S. Insulin-like growth factor-1 inhibits 6-hydroxydopamine-mediated endoplasmic reticulum stress-induced apoptosis via regulation of heme oxygenase-1 and Nrf2 expression in PC12 cells. International Journal of Neuroscience 2012122 641-649.

28 Xie HR, Hu LS \& Li GY. SH-SY5Y human neuroblastoma cell line: in vitro cell model of dopaminergic neurons in Parkinson's disease. Chinese Medical Journal 2010123 1086-1092.

29 Park YG, Jeong JK, Moon MH, Lee JH, Lee YJ, Seol JW, Kim SJ, Kang SJ \& Park SY. Insulin-like growth factor-1 protects against prion peptide-induced cell death in neuronal cells via inhibition of Bax translocation. International Journal of Molecular Medicine $2012 \mathbf{3 0}$ 1069-1074. (https://doi.org/10.3892/ijmm.2012.1087)

30 Currie RA, Walker KS, Gray A, Deak M, Casamayor A, Downes CP, Cohen P, Alessi DR \& Lucocq J. Role of phosphatidylinositol 3,4,5-trisphosphate in regulating the activity and localization of 3-phosphoinositide-dependent protein kinase-1. Biochemical Journal 1999337 575-583. (https://doi.org/10.1042/bj3370575)

31 Tasaki Y, Yamamoto J, Omura T, Noda T, Kamiyama N, Yoshida K, Satomi M, Sakaguchi T, Asari M, Ohkubo T, et al. Oxicam structure in non-steroidal anti-inflammatory drugs is essential to exhibit Aktmediated neuroprotection against 1-methyl-4-phenyl pyridiniuminduced cytotoxicity. European Journal of Pharmacology 2012676 57-63.

32 Chu AC, Ho PW, Kwok KH, Ho JW, Chan KH, Liu HF, Kung MH, Ramsden DB \& Ho SL. Mitochondrial UCP4 attenuates MPP+- and dopamine-induced oxidative stress, mitochondrial depolarization, and ATP deficiency in neurons and is interlinked with UCP2 expression. Free Radical Biology and Medicine 200946 810-820. (https://doi.org/10.1016/j.freeradbiomed.2008.12.015)

33 Nakamura K, Bindokas VP, Marks JD, Wright DA, Frim DM, Miller RJ \& Kang UJ. The selective toxicity of 1-methyl-4-phenylpyridinium to dopaminergic neurons: the role of mitochondrial complex I and reactive oxygen species revisited. Molecular Pharmacology 200058 271-278. (https://doi.org/10.1124/mol.58.2.271)

34 Avila-Gomez IC, Velez-Pardo C \& Jimenez-Del-Rio M. Effects of insulin-like growth factor-1 on rotenone-induced apoptosis in human lymphocyte cells. Basic and Clinical Pharmacology and Toxicology $201010653-61$.

35 Leinninger GM, Russell JW, van Golen CM, Berent A \& Feldman EL. Insulin-like growth factor-I regulates glucose-induced mitochondrial depolarization and apoptosis in human neuroblastoma. Cell Death and Differentiation 200411 885-896.

36 Russo VC, Gluckman PD, Feldman EL \& Werther GA. The insulin-like growth factor system and its pleiotropic functions in brain. Endocrine Reviews 200526 916-943.

37 Campana WM, Darin SJ \& O'Brien JS. Phosphatidylinositol 3-kinase and Akt protein kinase mediate IGF-I- and prosaptideinduced survival in Schwann cells. Journal of Neuroscience Research 199957 332-341. (https://doi.org/10.1002/(SICI)10974547(19990801)57:3<332::AID-JNR5>3.0.CO;2-0)

38 Mehrhof FB, Muller FU, Bergmann MW, Li P, Wang Y, Schmitz W, Dietz R \& von HR. In cardiomyocyte hypoxia, insulin-like growth factor-I-induced antiapoptotic signaling requires phosphatidylinositol-3-OH-kinase-dependent and mitogen-activated protein kinase-dependent activation of the transcription factor cAMP response element-binding protein. Circulation 2001104 2088-2094. (https://doi.org/10.1161/hc4201.097133)

39 Kang BP, Urbonas A, Baddoo A, Baskin S, Malhotra A \& Meggs LG IGF-1 inhibits the mitochondrial apoptosis program in mesangial cells exposed to high glucose. American Journal of Physiology: Renal Physiology 2003285 F1013-F1024. (https://doi.org/10.1152/ ajprenal.00209.2003)

40 Flynn P, Wongdagger M, Zavar M, Dean NM \& Stokoe D. Inhibition of PDK-1 activity causes a reduction in cell proliferation and survival. Current Biology 200010 1439-1442. (https://doi.org/10.1016/S09609822(00)00801-0)

41 Belham C, Wu S \& Avruch J. Intracellular signalling: PDK1 - a kinase at the hub of things. Current Biology 19999 R93-R96. (https://doi. org/10.1016/S0960-9822(99)80058-X)

42 Liu L, Xu H, Jiang H, Wang J, Song N \& Xie J. Ghrelin prevents 1-methyl-4-phenylpyridinium ion-induced cytotoxicity through antioxidation and NF-kappaB modulation in MES23.5 cells. Experimental Neurology 2010222 25-29. (https://doi.org/10.1016/j. expneurol.2009.11.009)

43 Zhou J, Sun Y, Zhao X, Deng Z \& Pu X. 3-O-demethylswertipunicoside inhibits $\mathrm{MPP}^{+}$-induced oxidative stress and apoptosis in PC12 cells. Brain Research 20131508 53-62. (https://doi.org/10.1016/j.brainres.2013.02.049)

44 Fleury C, Mignotte B \& Vayssiere JL. Mitochondrial reactive oxygen species in cell death signaling. Biochimie 200284 131-141. (https:// doi.org/10.1016/S0300-9084(02)01369-X)

45 Kajstura J, Fiordaliso F, Andreoli AM, Li B, Chimenti S, Medow MS, Limana F, Nadal-Ginard B, Leri A \& Anversa P. IGF-1 overexpression inhibits the development of diabetic cardiomyopathy and angiotensin II-mediated oxidative stress. Diabetes 200150 1414-1424. (https://doi.org/10.2337/diabetes.50.6.1414)

46 Gustafsson H, Soderdahl T, Jonsson G, Bratteng JO \& Forsby A. Insulin-like growth factor type 1 prevents hyperglycemia-induced uncoupling protein 3 down-regulation and oxidative stress. Journal of Neuroscience Research 200477 285-291. (https://doi.org/10.1002/ jnr.20142)

47 Pi Y, Goldenthal MJ \& Marín-García J. Mitochondrial involvement in IGF-1 induced protection of cardiomyocytes against hypoxia/ reoxygenation injury. Molecular and Cellular Biochemistry 2007301 181-189. (https://doi.org/10.1007/s11010-007-9410-0)

48 Pugazhenthi S, Miller E, Sable C, Young P, Heidenreich KA, Boxer LM $\&$ Reusch JE. Insulin-like growth factor-I induces bcl-2 promoter through the transcription factor cAMP-response element-binding protein. Journal of Biological Chemistry 1999274 27529-27535.

49 Sidoti-de FC, Rincheval V, Risler Y, Mignotte B \& Vayssiere JL. TNF-alpha activates at least two apoptotic signaling cascades. Oncogene 199817 1639-1651. (https://doi.org/10.1038/ sj.onc.1202094)

50 Indo HP, Davidson M, Yen HC, Suenaga S, Tomita K, Nishii T, Higuchi M, Koga Y, Ozawa T \& Majima HJ. Evidence of ROS generation by mitochondria in cells with impaired electron transport chain and mitochondrial DNA damage. Mitochondrion $2007 \mathbf{7}$ 106-118. (https://doi.org/10.1016/j.mito.2006.11.026)

51 Turrens JF. Mitochondrial formation of reactive oxygen species. Journal of Physiology 2003552 335-344. (https://doi.org/10.1113/ jphysiol.2003.049478)

52 Di Meo S, Reed TT, Venditti P \& Victor VM. Role of ROS and RNS sources in physiological and pathological conditions. Oxidative Medicine and Cellular Longevity 201620161245049.

53 Yi F, He X \& Wang D. Lycopene protects against MPP(+)-induced cytotoxicity by maintaining mitochondrial function in SH-SY5Y cells. Neurochemical Research 201338 1747-1757. (https://doi. org/10.1007/s11064-013-1079-z)

54 Bindoff LA, Birch-Machin MA, Cartlidge NE, Parker WD \& Turnbull DM. Respiratory chain abnormalities in skeletal muscle from patients with Parkinson's disease. Journal of the Neurological Sciences 1991104 203-208. (https://doi.org/10.1016/0022510X(91)90311-T)

55 Rustin P, Munnich A \& Rötig A. Succinate dehydrogenase and human diseases: new insights into a well-known enzyme. European 
Journal of Human Genetics 200210 289-291. (https://doi.org/10.1038/ sj.ejhg.5200793)

56 Johnson KR, Gagnon LH, Longo-Guess C \& Kane KL. Association of a citrate synthase missense mutation with age-related hearing loss in A/J mice. Neurobiology of Aging 201233 1720-1729. (https://doi. org/10.1016/j.neurobiolaging.2011.05.009)

57 Rasheed MZ, Tabassum H \& Parvez S. Mitochondrial permeability transition pore: a promising target for the treatment of Parkinson's disease. Protoplasma 2017254 33-42. (https://doi.org/10.1007/ s00709-015-0930-2)

58 Yuan J \& Yankner BA. Apoptosis in the nervous system. Nature 2000 407 802-809. (https://doi.org/10.1038/35037739)

59 Lindsay J, Esposti MD \& Gilmore AP. Bcl-2 proteins and mitochondria - specificity in membrane targeting for death.
Biochimica et Biophysica Acta 20111813 532-539. (https://doi. org/10.1016/j.bbamcr.2010.10.017)

60 Chong SJ, Low IC \& Pervaiz S. Mitochondrial ROS and involvement of Bcl-2 as a mitochondrial ROS regulator. Mitochondrion 201419 39-48. (https://doi.org/10.1016/j.mito.2014.06.002)

61 Ye Q, Chen C, Si E, Cai Y, Wang J, Huang W, Li D, Wang Y \& Chen X. Mitochondrial effects of PGC-1alpha silencing in $\mathrm{MPP}(+)$ treated human SH-SY5Y neuroblastoma cells. Frontiers in Molecular Neuroscience 201710 164. (https://doi.org/10.3389/fnmol.2017.00164)

62 Cheng B, Maffi SK, Martinez AA, Acosta YP, Morales LD \& Roberts JL. Insulin-like growth factor-I mediates neuroprotection in proteasome inhibition-induced cytotoxicity in SH-SY5Y cells. Molecular and Cellular Neuroscience 201147 181-190. (https://doi.org/10.1016/j. neuroscience.2011.08.011)

Received in final form 14 February 2018

Accepted 19 February 2018

Accepted Preprint published online 19 February 2018 http://www.endocrineconnections.org https://doi.org/10.1530/EC-17-0350
() 2018 The authors Published by Bioscientifica Ltd

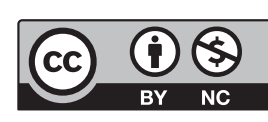

This work is licensed under a Creative Commons Attribution-NonCommercial 4.0 International License. 